\title{
BCR-mediated apoptosis associated with negative selection of immature B cells is selectively dependent on Pten
}

\author{
Shuhua Cheng ${ }^{1}$, Constance Yu Hsia ${ }^{1}$, Biao Feng ${ }^{1}$, Mei-Ling Liou ${ }^{2}$, Xiaoying Fang ${ }^{3}$, Pier Paolo Pandolfi, \\ Hsiou-Chi Liou
}

${ }^{I}$ Department of Medicine, Division of Immunology, Weill Medical College of Cornell University, New York, NY 10021, USA; ${ }^{2} D e-$ partment of Cancer Biology, University of California, Los Angeles, CA 92129, USA; ${ }^{3}$ Hunter College, City University of New York, New York, NY 10021, USA; ${ }^{4}$ Department of Pathology, Beth Israel Deaconess Medical Center, Harvard Medical School, Boston, MA 02115, USA

The molecular basis of $B$ cell receptor (BCR)-induced apoptosis during the negative selection of immature $B$ cells is largely unknown. We use transitional immature B cells that are highly susceptible to BCR-induced apoptosis to show that Pten is selectively required for BCR-mediated initiation of the mitochondrial death pathway. Specifically, deleting Pten, but not other pro-apoptotic molecules, abrogates BCR-elicited apoptosis and improves viability in wild-type immature B cells. We further identify a physiologically and significantly higher intracellular Pten level in immature B cells, as compared to mature B cells, which is responsible for low AKT activity and the propensity towards death in immature B cells. Restoration of AKT activity using a constitutive form of AKT or reduction of Pten to a level comparable with that seen in mature B cells rescues immature B cells from BCR-induced apoptosis. Thus, we provide evidence that Pten is an essential mediator of BCR-induced cell death, and that differential regulation of intracellular Pten levels determines whether BCR ligation promotes cell death or survival. Our findings provide a valuable insight into the mechanisms underlying negative selection and clonal deletion of immature $B$ cells.

Keywords: B cell receptor, apoptosis, B cell tolerance, Pten

Cell Research (2009) 19:196-207. doi: 10.1038/cr.2008.284; published online 9 September 2008

\section{Introduction}

The $\mathrm{B}$ cell receptor (BCR) is a complex receptor possessing a unique ability to transmit functionally divergent signals [1]. BCR ligation by foreign antigens on mature $\mathrm{B}$ cells induces pro-survival and mitogenic proliferation to elicit a protective immune response against pathogens.

Correspondence: Shuhua Cheng ${ }^{\mathrm{a}}, \mathrm{H}$ siou-Chi Liou ${ }^{\mathrm{b}}$

${ }^{\mathrm{a}} 515$ East 71 Street, S-222 New York, NY 10021, USA

Tel: +1-212-746-4409; Fax: +1-212-746-8167

E-mail: shc2019@med.cornell.edu

${ }^{\mathrm{b}} 515$ East 71 Street, S-210 New York, NY 10021, USA

Tel: +212-746-4451; Fax: +212-746-8167

E-mail: hcliou@med.cornell.edu

Abbreviations: BCR (B cell receptor); $\Delta \psi_{\mathrm{m}}$ (mitochondrial membrane potential); Pten (phosphatase with tensin homology on chromosome 10); AKT (protein kinase B); PI3K (phosphoinositide 3-kinase); PIP2 (phosphatidylinositol 4,5 diphosphate); PIP3 (phosphatidyl inositol 3,4,5 triphosphate); JNK (c-Jun N-terminal Kinase); PH (pleckstrin homology) Received 26 June 2008; revised 10 July 2008; accepted 10 July 2008; published online 9 September 2008
However, BCR engagement on immature B cells fails to initiate such "positive" signals, instead resulting in receptor editing, anergy (unresponsiveness), or cell death (clonal deletion) $[1,2]$. The first in vivo evidence of BCR-induced cell death was shown by injecting anti-IgM into newborn mice or chickens [3]. More recent studies confirmed this observation in several independent transgenic mouse models [4-6]. It is generally believed that the BCR-induced apoptosis of self-reactive immature $\mathrm{B}$ cells is one of the critical mechanisms underlying $\mathrm{B}$ lymphocyte immune tolerance and overall B lymphocyte homeostasis. Accordingly, defects in this apoptotic process may well contribute to the onset and development of autoimmune disease, B cell lymphoma, and leukemia. Understanding the signaling pathways that account for BCR-induced cell death is therefore important to the innovation and advancement of new therapies to treat these conditions.

Previous research reveals that a critical early event in BCR-induced apoptosis is the disruption of mitochon- 
drial membrane integrity $[7,8]$. During this process, collapse of the mitochondrial membrane potential $\left(\Delta \psi_{\mathrm{m}}\right)$ leads to release of cytochrome $c$ from the mitochondrial intermembrane space, promotes downstream DNA fragmentation, and commits cells to undergo irreversible apoptosis [9-11]. Recent research in the immature murine B cell line WEHI231 reveals that c-Jun NH2 terminal kinase (JNK), phospholipase A2, Swiprosin-1, and DNase $\gamma$ are involved in the activation or execution of the BCR-mediated mitochondrial death pathway [12-15]. In primary immature and self-reactive $\mathrm{B}$ cells, studies indicate that BCR-induced activation of the pro-apoptotic Bcl-2-related proteins Bim, Bax, and Bak is critical for triggering the mitochondrial death pathway $[16,17]$. However, beyond identification of these pro-apoptotic Bcl-2 family members, the death signaling mediators underlying initiation of BCR-induced mitochondrial death signaling in immature B cells remain largely undefined.

Previous studies, by comparing signaling differences between immature and mature B cells, have identified several deficits in immature B cells in engaging BCRinduced positive signals, including impaired activation of PKC, Akt, and Rel/NF-кB [18-21]. We have further shown that overexpression of c-Rel target genes, Bcl-X and cyclin $\mathrm{E}$, restores the survival and proliferative capacity of immature B cells [20], suggesting that the primary deficiency in immature B cells is due to an inability to activate the c-Rel-mediated survival and proliferative signaling pathway [22-25]. These observations prompt us to investigate upstream positive and negative signaling pathways that are known to regulate Rel/NF- $\mathrm{BB}$ activation in B cells.

$\mathrm{BCR}$ ligation in mature $\mathrm{B}$ cells leads to the activation of series of protein kinases, as well as lipid kinase phosphoinositide 3-kinase (PI3K) [26]. PI3K is instrumental in activating several downstream signaling molecules, including Akt, PLC $\gamma$, and PKC $\beta$, leading to the subsequent Rel/NF- $\kappa \mathrm{B}$ activation via the Carma1/Bcl10/Malt1 complexes [26, 27]. The link between PI3K and Rel/NF$\kappa \mathrm{B}$ activation has been further supported by the studies showing that $\mathrm{B}$ cells derived from the PI3K (p85 subunit) knockout mice have impaired Rel/NF- $\kappa \mathrm{B}$ activation, decreased Bcl-X expression, and enhanced apoptosis [28].

The remarkable resemblance of BCR-induced apoptotic response in immature $\mathrm{B}$ cells to the $\mathrm{B}$ cells deprived of the positive signaling molecules, such as PI3K (p85) and c-Rel, leads us to investigate the PI3K and its counteracting partner Pten (phosphatase with tensin homology on chromosome 10) activity in immature B cells as described in this study. PI3K mediates the production of phosphatidylinositol 3,4,5 triphosphate (PIP3) from phosphatidylinositol 4,5 diphosphate (PIP2). Pten is a lipid phosphatase that directly antagonizes PI3K by dephosphorylating PIP3 into PIP2. Pten dysfunction has been implicated in the onset and development of many tumors. Knockout mice also indicate the importance of Pten in lymphocyte homeostasis and immune tolerance. In Pten $^{+--}$or T lineage-specific Pten-deficient mice, autoimmune disease and leukemogenesis are observed, concurrent with impairment of Fas-mediated apoptosis of $\mathrm{B}$ and $\mathrm{T}$ cells and disruption of thymic and peripheral $T$ cell negative selection $[29,30]$. In B lineage-specific Pten-deficient mice $\left(\mathrm{CD} 19^{\mathrm{Cre} / \mathrm{H}} \mathrm{Pten}^{\text {Flox/Flox }}\right.$, hereafter referred to as Pten $^{\text {Flox/Flox }}$ ), B1 and marginal zone B cells (MZB) accumulate in peripheral lymphoid tissues and a higher titer of auto-antibodies is observed in the sera $[31,32]$. While these studies have considerably advanced our understanding of the function of Pten in the immune system, the role of Pten in BCR-mediated cell death and its purported role in clonal deletion of immature B cells remain unclear.

In the present study, we identify Pten, from among several candidates, as a crucial mediator of BCR-coupled death through the inhibition of PIP3-dependent signaling in immature B cells, a stage in which B cells are extremely vulnerable to clonal deletion.

\section{Results}

Pten is essential for BCR-induced death of immature $B$ cells

Previous studies have identified multiple signaling defects in immature $\mathrm{B}$ cells, including impaired activation of the Rel/NF- $\kappa \mathrm{B}$ transcription factors [18-21]. Introduction of Rel/NF- $\mathrm{B}$ target genes Bcl-X and cyclin $\mathrm{E}$ can restore the survival and proliferation of immature $\mathrm{B}$ cells, suggesting that the primary defect lies in the inability of BCR to activate the Rel/NF- $\kappa \mathrm{B}$-mediated positive signals. In searching for the signaling deficit downstream of BCR and upstream of Rel/NF- $\mathrm{KB}$, we investigated the PI3K and Pten signaling pathway in immature B cells for the following reasons. First, PI3K has been shown to be required for Rel/NF- $\kappa \mathrm{B}$ activation and provide survival and proliferative signals to B cells. Deletion of PI3K (p85 subunit) led to impaired Rel/NF- $\kappa \mathrm{B}$ activation, growth arrest, and apoptosis of B cells [33, 34]. Second, deletion of Pten phosphatase in $\mathrm{T}$ cell lineage led to defective negative selection in $\mathrm{T}$ cell compartment and autoimmune manifestation [30], raising the possibility that Pten may also be involved in the regulation of $\mathrm{B}$ cell immune tolerance.

To investigate whether Pten plays a role in the negative selection of immature $B$ cells through clonal deletion, we have generated B lineage-specific Pten-depleted 

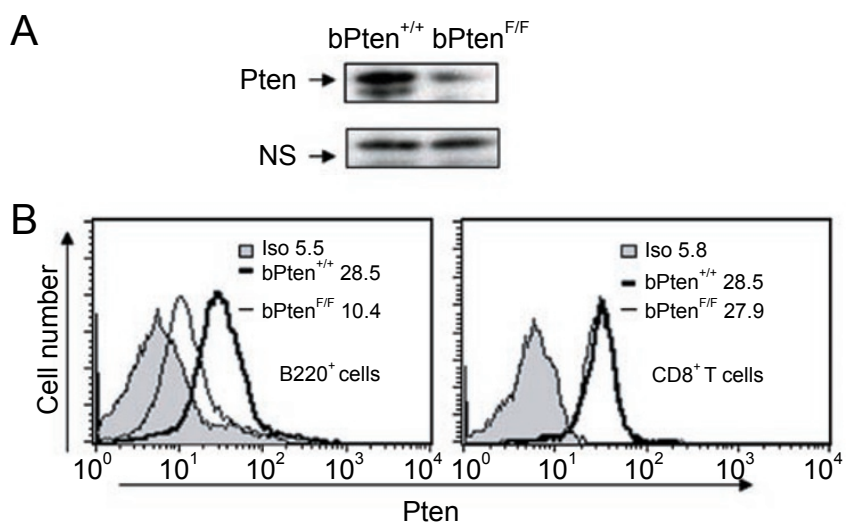

C

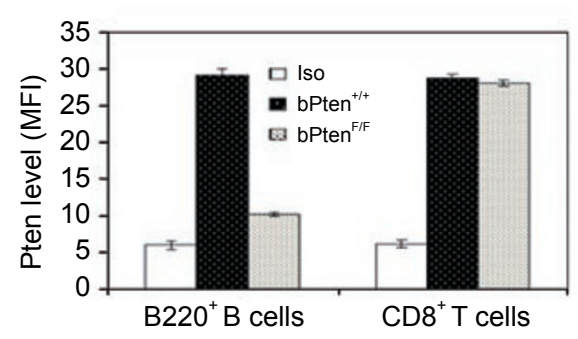

Figure 1 Generation of B lineage-specific Pten-depleted mice. (A) Immunoblot analysis of Pten protein expression level in freshly purified B cells from wt and B cell-specific Pten-depleted mice. NS, nonspecific band as a loading control. (B) Determination of intracellular Pten protein level by FACS in CD8T and B cells. Iso, isotype control. Numbers within each histogram are median fluorescent intensities (MFI) of intracellular Pten staining for the B or T cells with the designated genotypes. One result representative of five independent experiments is shown. (C) Data summary of five independent experiments described in (B). Where appropriate in all figures, the results are expressed as the mean $\pm \mathrm{SD}$ of the indicated parameter per group.

mice $\left(\right.$ PPten $\left.^{\text {Flox/Flox }}\right)$. Substantial reduction $(\sim 80 \%$ on the basis of Pten levels in wild-type B cells), but not complete absence, of Pten expression in B cells (B220 ${ }^{+}$) was observed as confirmed at the protein level by both Western blot (Figure 1A) and a FACS-based intracellular staining approach (Figure 1B and 1C). This is consistent with the previous finding showing that, at DNA level, the Pten loci are not completely deleted in bPten Flox/Flox splenic B cells [35]. By contrast, in CD8 T cells isolated from bPten $^{+++}$and PPten $^{\text {Flox/Flox }}$ mice, the intracellular Pten level was comparable (Figure 1B and 1C). This result verified that the observed Pten depletion was specific for B-cell lineage, and that the antibody used was specific against Pten protein. To enrich a sufficient amount of immature B cells for our experiments, we used a method established previously by another group [36]. B cells isolated at 14 days post-sublethal irradiation consist primarily of immature B cell populations, which can be identified using cell surface markers CD24/CD21 and
$\operatorname{IgM} / \operatorname{IgD}$ to define immature phenotypes. Following this method, we obtained the cells that were $80-90 \%$ pure for

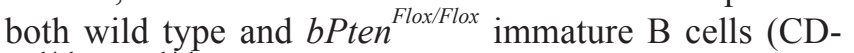
$24^{\text {high }}$, IgM $^{\text {high }}$; Figure 2A).

In line with previous studies, anti-IgM treatment induced a complete loss of $\Delta \psi_{\mathrm{m}}$ in the majority of wildtype immature B cells (viability of mature B cells vs. that of immature B cell counterparts $=45 \%$ vs. $15 \%$; Figure 2B). In contrast, the decreased Pten activity in immature $\mathrm{B}$ cells negated BCR-induced death signaling and effectively hindered mitochondrial membrane depolarization (Figure 2B). Interestingly, propidium iodide (PI) staining demonstrated that the $\mathrm{B}$ lineage-specific reduction of Pten protein level not only blocked DNA fragmentation but also significantly restored BCR-induced cell cycle progression in immature B cells (Figure 2C and 2D). These data suggest that Pten is a key regulator simultaneously governing both survival and cell cycle progression of B cells upon BCR engagement, presumably by controlling AKT activity. In fact, Akt has been shown to regulate cell survival via inactivation of caspase and the pro-apoptotic Bcl-2 members, Bad and Bim. Akt also facilitates G1-S cell cycle progression via inhibition of p130 and p27-kip1 expression. Therefore, PTEN loss not only rescues the B cells from apoptosis but also allows the cells responding to mitogenic signal and entering the cell cycle. These data indicate that Pten plays the crucial dual roles in BCR-mediated death signaling pathway and BCR-induced cell cycle arrest in immature B cells.

We also observed that the average number of reconstituted immature B cells in $b P T E N^{\text {floxflox }}$ mice at 14 days post-irradiation is 2.0-2.5 times greater than that observed in wild-type control mice (Figure 2E). The increased accumulation of immature cells in $b P T E N^{f l o x}$ flox mice may be a consequence of disrupted Pten-dependent negative selection processes in vivo.

A number of intracellular signal mediators, including JNK2 and E2F1, have been shown to be involved in TCR-induced cell death at specific stages of T lymphocyte development, possibly via the activation of the mitochondrial death pathway [37-40]. We therefore investigated immature B cells derived from the $E 2 \mathrm{Fl}^{-/-}$ or $J N K 2^{--}$mice. Our studies showed that these signaling molecules are not required for BCR-induced apoptosis of immature B cells (Supplementary information, Figure S1).

In summary, our data support the conclusion that Pten selectively plays a critical role in antigen receptor-mediated negative selection of immature $B$ cells.

Pten uncouples PI3K/AKT-mediated survival in BCRstimulated immature B cells 
A

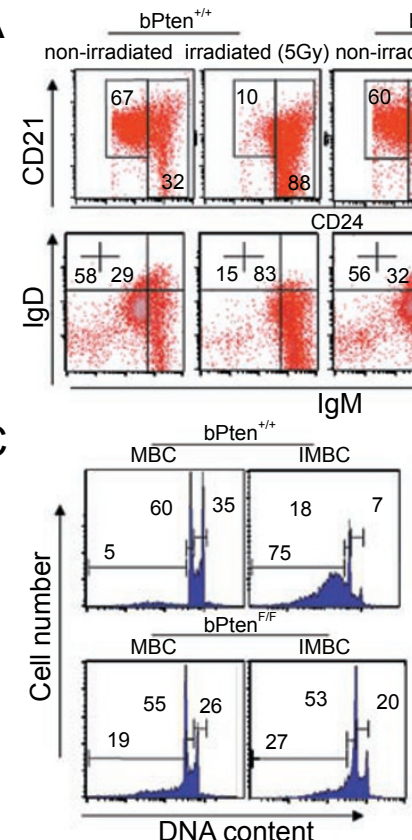

bPten $^{\mathrm{F} / \mathrm{F}}$

ted irradiated (5Gy)
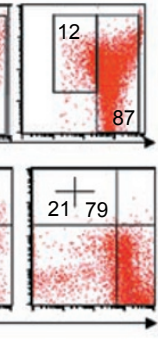

D

B
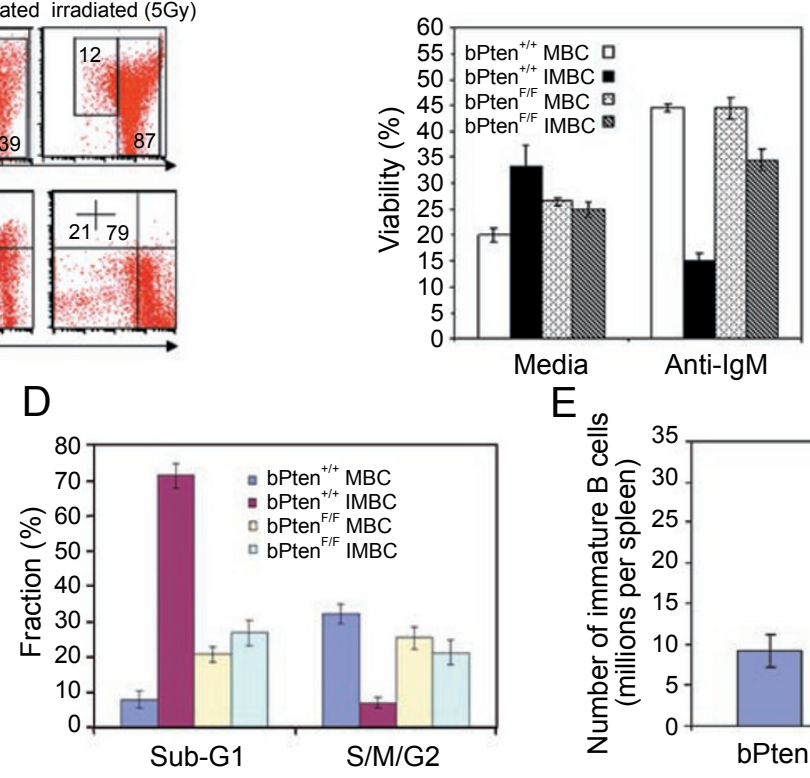

E

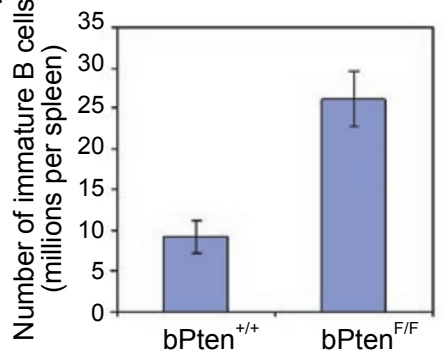

Figure 2 Pten is essential for BCR-induced death signaling in immature B cells. (A) Mature and immature B cells isolated from the mice with the indicated genotypes were stained for CD21 and CD24, or IgM and IgD surface expression. The percentage of mature CD24 ${ }^{\text {lo }}$ or $\operatorname{IgM}^{\text {lo }} \mathrm{B}$ cells and immature $\mathrm{CD} 24^{\text {hi }}$ or $\operatorname{IgM}^{\text {hi }} \mathrm{B}$ cells is shown in each dot plot and the results are representative of six age-matched pairs of mice examined in each group. (B, C) MBC and IMBC were cultured in the presence or absence of $10 \mu \mathrm{g} / \mathrm{ml} \mathrm{of} \mathrm{anti-IgM} \mathrm{for} 24 \mathrm{~h}(\mathrm{~B})$ or $48 \mathrm{~h}(\mathrm{C})$. Viability and cell cycle progression were respectively analyzed by JC-1 (B) or propidium iodide (C) staining as described in Materials and Methods. (D) Data summary of three independent experiments as shown in (C). The results are expressed as the mean $\pm \mathrm{SD}$ of the indicated parameter per group. Sub-G1 represents apoptotic cells that undergo DNA fragmentation, and S/M/G2 represents cells

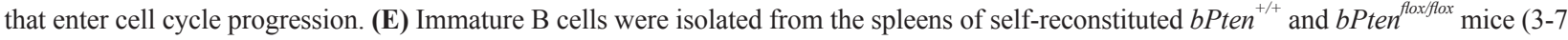
mice per genotype) on day 14 post-irradiation, and cell types enumerated. The mean cell number $\pm \mathrm{SD}$ from a single experiment is shown here. Hereafter, $\mathrm{MBC}$ is referred as mature $\mathrm{B}$ cells, IMBC, immature $\mathrm{B}$ cells.

Because Pten hydrolyzes PIP3 into PIP2 to antagonize PI3K/AKT activation, we next examined whether BCRmediated PIP3 production differs in immature vs. mature B cells. Using a PIP3-specific antibody [32], we observed that BCR stimulation of mature B cells led to an early (5 $\mathrm{min})$ and late (120 min) wave of intracellular PIP3 accumulation (Figure 3A). Interestingly, immature B cells generated virtually no detectable increase in intracellular PIP3 levels upon antigen receptor ligation. Using phosphospecific antibodies, we further observed that BCR stimulation led to the downstream anti-apoptotic and PIP3-dependent AKT activation in mature but not immature B cells (Figure 3B), consistent with a previously reported observation [21]. Hence BCR signals do not appear to activate AKT in immature $B$ cells.

However Pten catalyzes the hydrolysis of PIP3 to PIP2, PI3K reversely catalyzes the production of PIP3 from PIP2. To further define the molecular mechanism of AKT inactivation in immature B cells, we directly measured PI3K activity in these cells using immunoprecipitation and TLC-based in vitro kinase assay. BCR-de- pendent $\mathrm{PI} 3 \mathrm{~K}$ activation was reduced in primary immature B cells (Figure 3C). In contrast, BCR stimulation of mature $\mathrm{B}$ cells led to early and sustained PI3K activation. To test whether Pten plays a predominant role over the weak PI3K activity in suppressing AKT activation, we measured AKT activation status in beten $^{+/+}$vs. bPten ${ }^{\text {Flox }}$ ${ }^{\text {Flox }}$ immature B cells by immunoblot assay. Pten loss completely restores AKT activity in immature B cells to a level comparable to mature B cells (Figure 3D). These data thus suggest that Pten activity primarily contributes to the inhibition of BCR-induced AKT activation in immature $B$ cells.

We next tested whether directly restoring AKT activity can protect immature B cells from BCR-induced apoptosis and override Pten activity. To do this, we introduced a constitutively active form of AKT (hereafter named as pMyr-AKT-HA) or control empty vector (hereafter named as pMIGR1, both vectors were tagged with green fluorescence protein GFP) into immature B cells by retroviral gene transduction and bone marrow transfer (Figure 4) [41]. The effective expression of Myr- 
AKT-HA was confirmed in retrovirus-infected fibroblast cells by immunoblot against the HA tag (Figure 4B). To circumvent the issue of quenching the GFP signal by PI, we used an FSC/SSC-based assay to measure the percents of viable vs. apoptotic cells and validated this using JC-1 staining (Figure 4C, the left lower panel). At 14 days post-transplantation, immature $\mathrm{B}$ cells derived from bone marrow stem cells infected with pMyr-AKT-HA or pMIGR1 were harvested from spleens and stimulated with anti-IgM. After $48 \mathrm{~h}$, only $33 \%$ of the GFP-positive immature B cells remained viable in the pMIGR1 control group (Figure 4C and 4D). In contrast, the pMyr-AKTHA-infected immature B cells gave rise to $69 \%$ viability in the GFP-positive population, an increase of $109 \%$ compared to the control pMIGR1-infected immature B cells. These data indicate that AKT activation can sufficiently protect immature B cells from BCR-induced apoptosis.

Together, our data demonstrate that Pten-dependent uncoupling of BCR with AKT activation is critical for BCR-induced immature B cell death.

High Pten levels render immature B cells susceptible to BCR-induced apoptosis
A predominant role for Pten in uncoupling BCR signaling with AKT activation in immature $\mathrm{B}$ cells implies that Pten activity might be differentially regulated in mature vs. immature B cells. Studies suggest that in its natural state, Pten is constitutively active and regulated by several mechanisms, including its expression level [42]. We therefore hypothesized that BCR signaling-mediated differential survival responses in mature vs. immature B cells may result from a quantitative difference in intracellular Pten levels.

Using an antibody against Pten and an intracellular staining approach as described in Figure 1, we compared the expression levels of Pten in mature and immature cells. Mature and immature B cell subpopulations in freshly isolated splenocytes were gated based on B220 and AA4.1 expression on the surface of the cells (MBC, $\mathrm{B} 220^{+} \mathrm{AA} 4.1^{-}$; IMBC, B220 ${ }^{+} \mathrm{AA} 4.1^{+}$; Figure $5 \mathrm{~A}$, left panel). AA4.1, besides CD24, is another specific surface marker for immature B cells [43]. The intracellular staining clearly revealed that Pten levels in immature $\mathrm{B}$ cells is $50-60 \%$ higher than in mature $\mathrm{B}$ cell counterparts (Figure 5A, middle and right panels). Coincidently, this physiological and quantitative Pten level difference between wild-type mature and immature B cells (MFI,
A

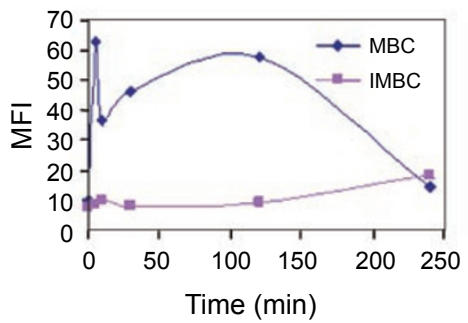

B

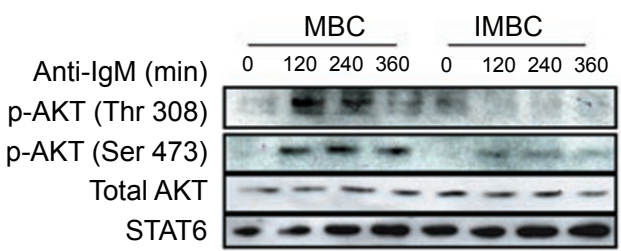

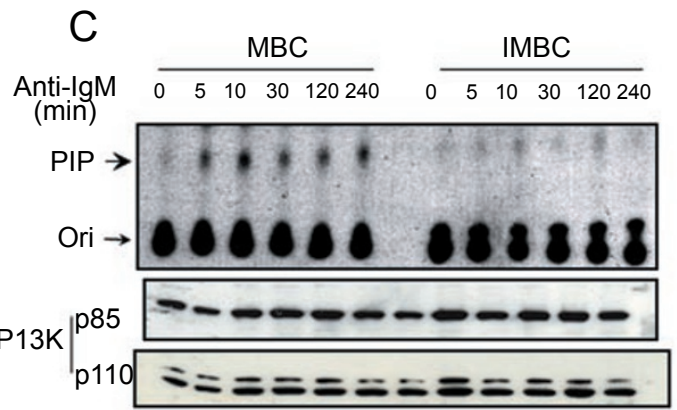

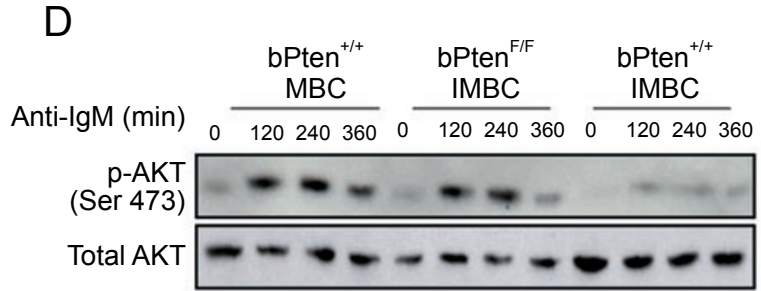

Figure 3 Insufficient PI3K/AKT activation by BCR ligation in immature B cells is Pten-dependent. (A) PIP3 production in mature and immature B cells stimulated by $10 \mu \mathrm{g} / \mathrm{ml}$ of anti-IgM for the indicated duration was assayed using a specific biotinylated antibody against PIP3 and flow cytometry. Median fluorescent intensities (MFI) corresponding PIP3 levels are shown. Data are representative of two independent experiments. (B, D) BCR-induced AKT activity in mature and immature splenic B cells was measured by immunoblot assay with phospho-specific AKT antibodies. (C) BCR-induced PI3K activity was assayed by an immunoprecipitation and TLC-based assay to measure the conversion of phosphatidyl inositol (PI) substrate to phosphatidyl inositol phosphate (PIP), as described in Materials and Methods. Bottom two panels are immunoblots with specific antibodies directed against the p 85 and p110 subunits of PI3K. Stat6 and total AKT antibodies were used to verify equivalent loading of each lane. All data shown (B-C) are representative of five independent experiments. 


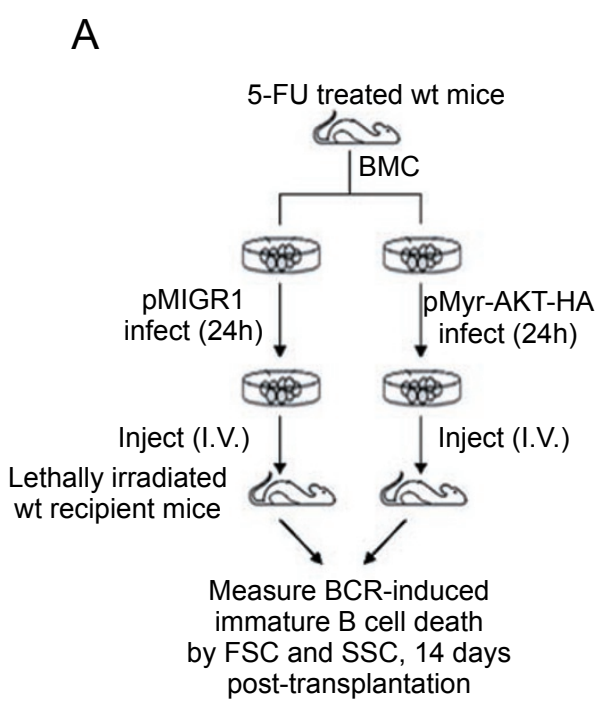

B

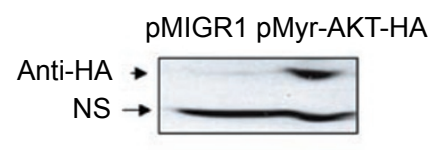

C

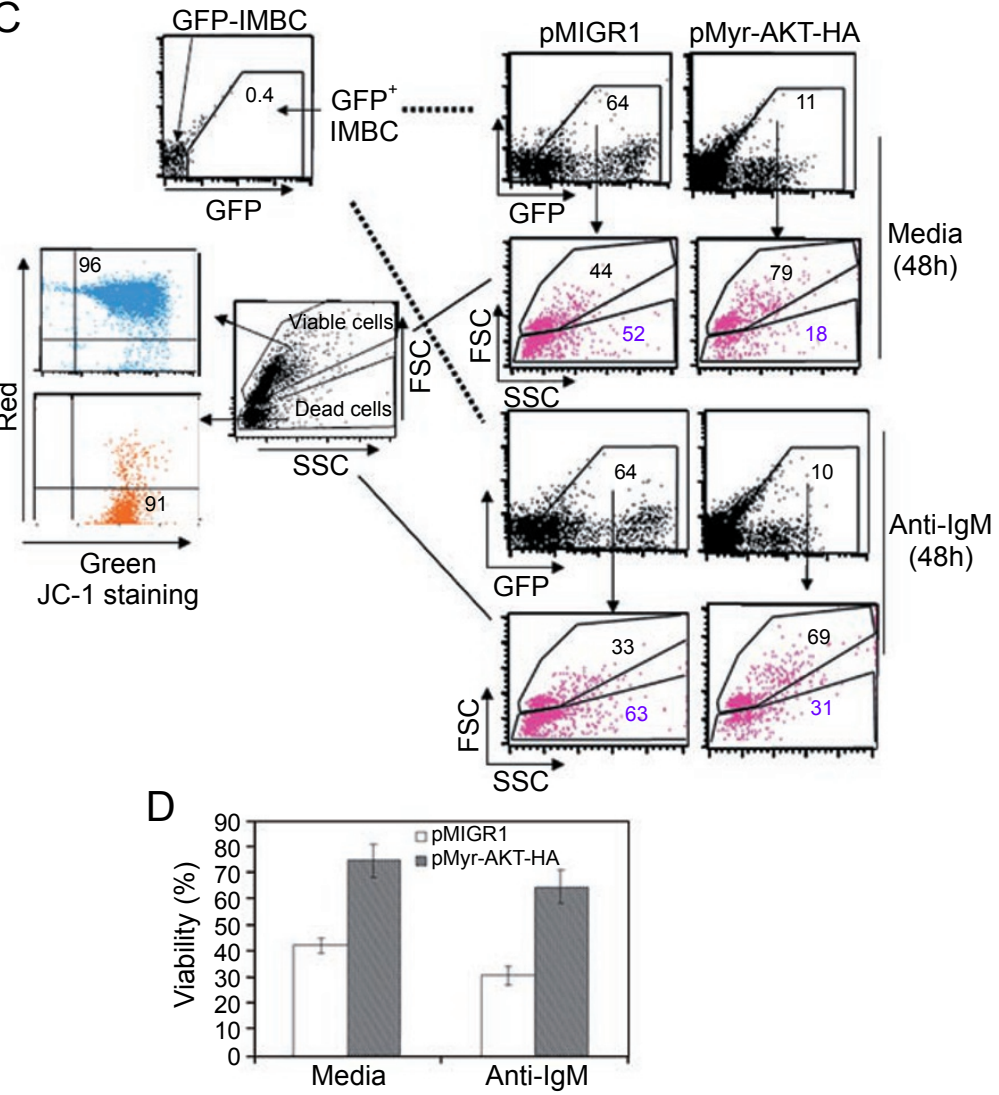

Figure 4 Constitutively active AKT restores the survival of BCR-activated immature B cells. (A) A diagram illustrates the procedure for introducing Myr-AKT-HA retrovirus into immature B cells. Bone marrow stem cells (BMC) isolated from 5-FU-treated wild-type mice were infected with pMyr-AKT-HA or pMIGR1 retroviruses for $24 \mathrm{~h}$, and then injected into pre-irradiated recipient mice. At 14 days posttransplantation, immature B cells were isolated, cultured with $10 \mu \mathrm{g} / \mathrm{ml}$ anti-IgM, and analyzed for BCR-induced apoptosis. (B) The effective expression of pMyr-AKT-HA protein in transduced NIH3T3 cells is shown. NIH3T3 cells were cultured for $48 \mathrm{~h}$ post-retroviral infection with pMyr-AKT-HA or pMIGR1 and cell lysates were measured for Myr-AKT-HA expression by immunoblotting with a specific antibody against HA. A non-specific (NS) band on the blot was used to verify equivalent loading of each lane. (C) The left upper and lower panels illustrate the gating diagram used in flow cytometry to identify GFP positive (GFP ${ }^{+}$) vs. GFP negative (GFP) as well as viable vs. dead cells. $\mathrm{GFP}^{+}$cells were further analyzed by SSC and FSC parameters to identify viable and dead cell populations. Cell viability within the selected gates was confirmed by JC-1 staining. In the right panel, numbers in each gate denotes the percentage of cells that are $\mathrm{GFP}^{+}$(1st and 3rd rows), viable, or apoptotic (2nd and 4th rows). These data are representative of two independent experiments. (D) Summary of immature B cell viability measured by SSC/FSC-based assay in the two independent experiments described in (C). The results are expressed as the mean $\pm \mathrm{SD}$ of the viability per group with the indicated conditions.

$\mathrm{IMBC} / \mathrm{MBC}=45.1 / 26.8$; Figure 5B) is approximately equal to the observed difference between wild type ( $b P$ ten $\left.^{+++}\right)$and heterozygous (bPten $\left.{ }^{\text {Flox/+ }}\right)$ immature B cells

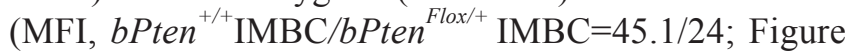
$5 \mathrm{~B})$. These results unequivocally indicate that immature $\mathrm{B}$ cells express approximately twice as much Pten as mature B cells.

Since a subtle change (e.g. 25\%) in intracellular Pten levels leads to profound effects on cellular survival and tumorigenesis [44], the 50-60\% Pten level increase described above might render enhanced susceptibility of immature B cells to BCR-induced apoptosis. As shown in Figure 5B, the intracellular Pten levels in wild-type MBCs and Pten heterozygous IMBCs are comparable. This observation allows us to test whether reducing the Pten expression of immature B cells to a level comparable with that in mature $B$ cells can affect immature $B$ cell apoptotic response to BCR engagement. Our data showed that indeed a $\sim 50 \%$ reduction of Pten significantly blocked BCR-induced death and improved the viability of BCR-stimulated immature B cells (Figure 5C). This improvement in viability is almost equivalent to the one achieved in bPten Flox/Flox immature B cells (Figure 5C), indicating that maintaining certain higher intracellular 
Pten level is crucial for susceptibility of immature B cells to BCR-induced apoptosis. Together, our data suggest that differential intracellular Pten levels may dictate the survival fate of B cells, and provide a potential mechanism to explain the negative selection of potentially selfreactive immature $\mathrm{B}$ cells.

\section{Discussion}

BCR-induced cell death is an important immunological process for the negative selection of immature B cells in establishing tolerance and the overall homeostasis of the B cell lineage. A better understanding of key BCRlinked death signaling mediators that govern mitochondrial-dependent death or survival pathways is important to the development of future therapies for autoimmune diseases, leukemia, and lymphomas. By using primary mature and immature B cells, our present study shows that Pten is an essential and selective mediator for the initiation of mitochondrial-dependent death signaling in BCR-induced apoptosis, and that higher Pten levels in immature B cells can promote BCR-induced apoptosis by uncoupling BCR signaling with PI3K/AKT activation. Unlike deletion of other potential death mediators, Pten loss preserves mitochondrial membrane potential and prevents DNA fragmentation, and can also override
BCR-associated cell cycle arrest (Figure 2). In immature B cells, the inability of the BCR to activate PI3K and AKT is primarily attributed to unabrogated PTEN activity, since loss of PTEN completely restores AKT activation (Figure 3). Sustained inhibition of AKT/PI3K activation through Pten activity appears important for the negative selection of immature B cells, an effect that can be overridden by constitutive AKT activity (Figure 4). Interestingly, we found that intracellular Pten levels are twice as high in immature B cells than in mature B cell counterparts (Figure 5). The importance of high intracellular Pten levels in driving apoptosis is highlighted by the fact that an about $50 \%$ Pten reduction in immature B cells, to a level comparable to that in mature B cells, notably blocks BCR-induced apoptosis of immature B cells (Figure 5C). These results thus demonstrate the crucial qualitative and quantitative role of Pten in BCR-induced death of immature B cells.

Our present results also corroborate previously reported signaling deficiencies in immature B cells and allow us to propose a central role for differential Pten/PI3K and $\mathrm{NF}-\kappa \mathrm{B} /$ Rel signaling in determining the cellular fate of mature and immature B cells (Figure 6). In mature B cells, BCR ligation initiates the assembly of a signaling complex that contains tyrosine kinases (Lyn, Syk), adaptor molecules (BLNK, BCAP), and downstream kinases.

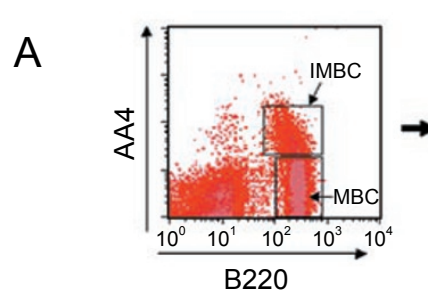

B

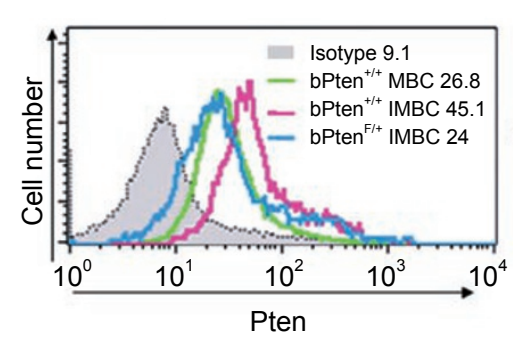

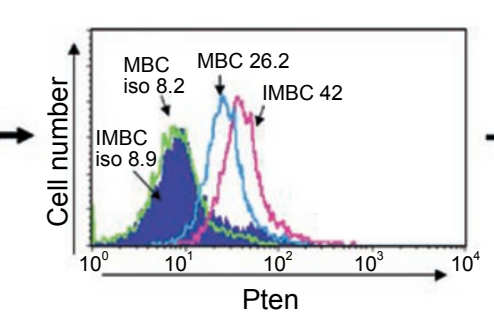
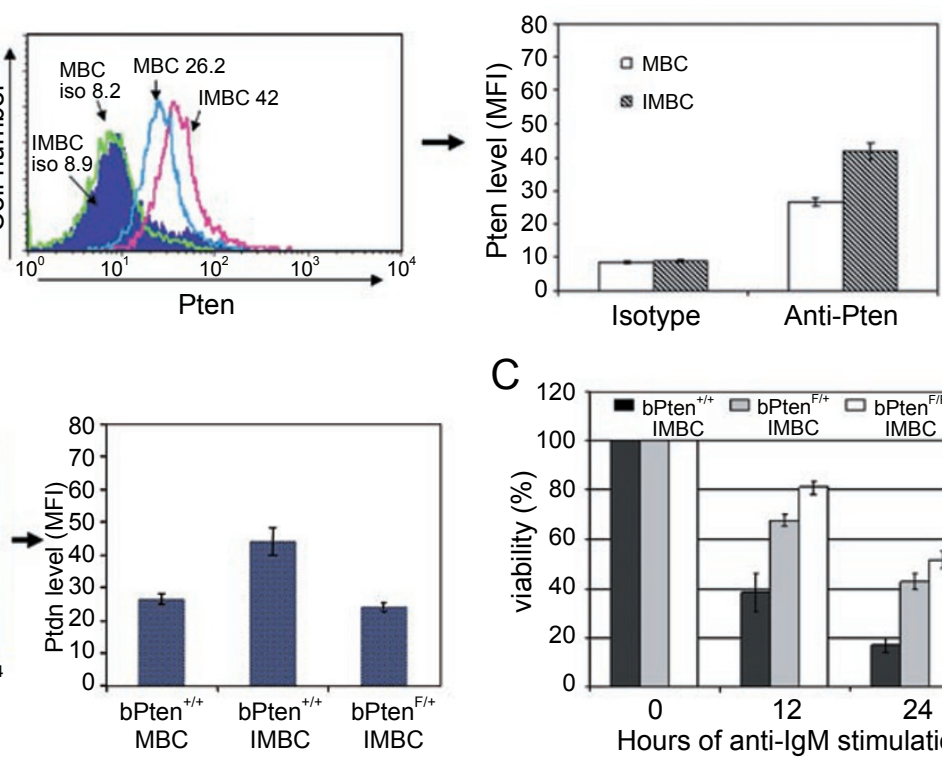

C

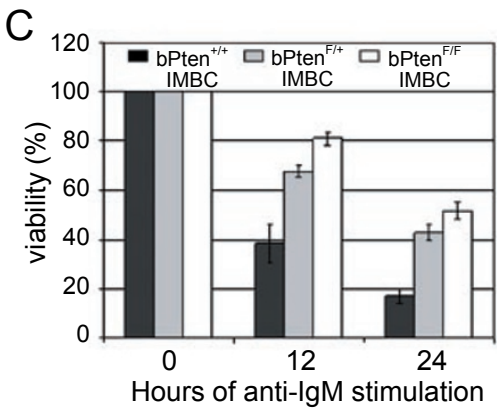

Figure 5 Differential intracellular Pten levels are associated with distinct survival fate of mature and immature B cells upon BCR engagement. (A) Wild-type immature B cells express higher Pten levels. Wild-type mature (MBC) and transitional immature (IMBC) B cells in the freshly isolated splenocytes were stained by the antibodies against B220, AA4.1 and Pten. Intracellular Pten levels were measured by median fluorescence intensity (MFI). Panels from left to right are representative and summary of five separate experiments. Numbers in histograms are MFI. Iso, antibody isotype control. (B) Comparable Pten level between wild-type MBCs and bPTEN ${ }^{\mathrm{Flox} /+}$ IMBCs. (C) The viability of the genotype-indicated immature B cells stimulated by anti-IgM was analyzed by a combination of PI exclusion and B220/ AA4.1 staining, as described in Materials and Methods. The data are representative of two independent experiments. 

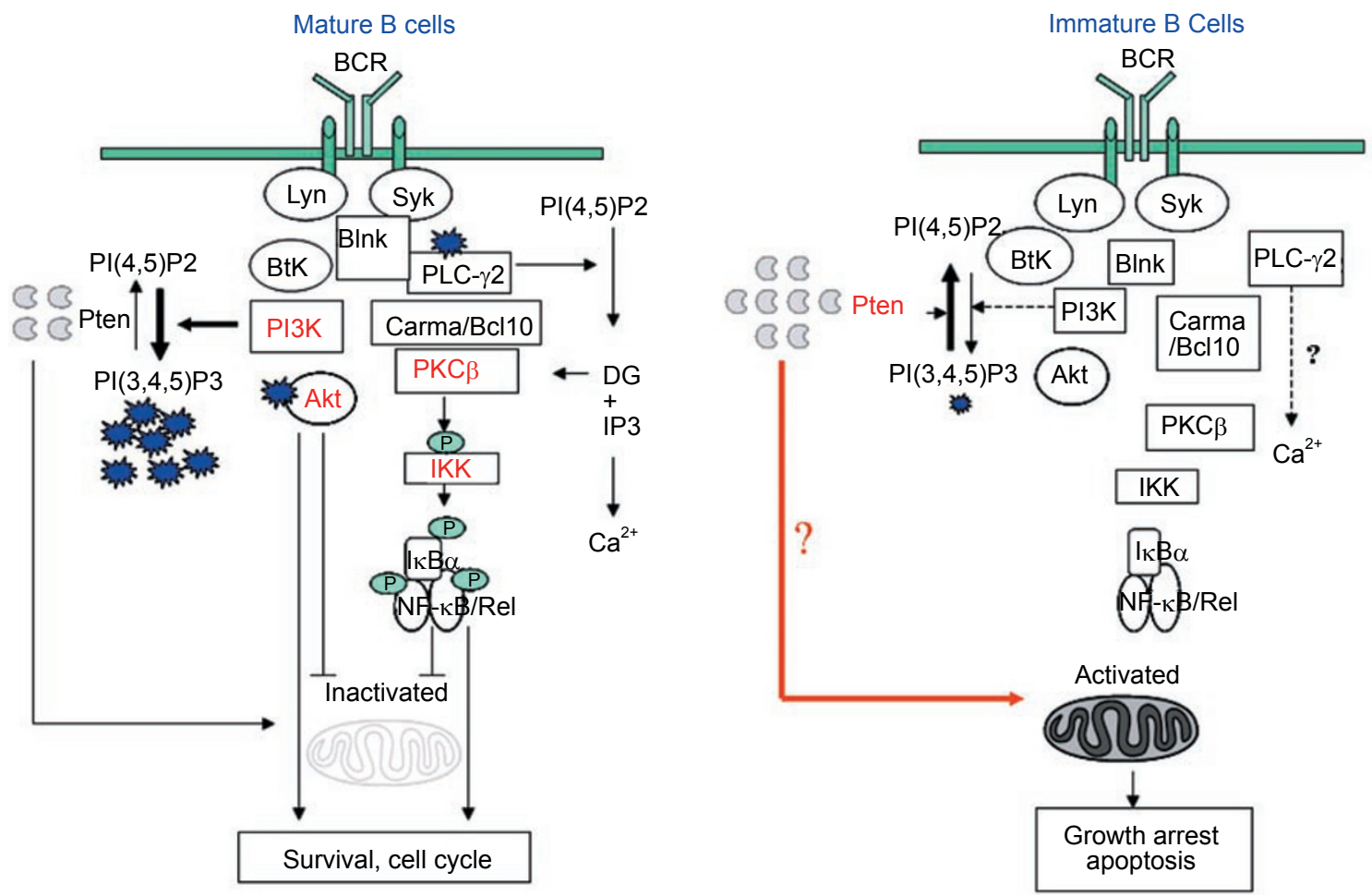

Figure 6 Proposed mechanism by which BCR induces opposing survival and death signals in mature and immature B cells. In mature B cells, BCR engagement by foreign antigens activates tyrosine kinases (e.g., Lyn, Syk) and recruits adaptor proteins (e.g. Blnk). This in turn activates PI3K with minimal or no impact on Pten activity. As a result of dominant PI3K activity over Pten activity, intracellular PIP3 accumulates and activates the downstream PIP3-dependent AKT and PLC $\gamma$. The activation of the NF- $\mathrm{kB} /$ Rel survival pathway results in the blockade of mitochondrial-dependent apoptotic pathways and promotion of survival and cell cycle progression. In immature B cells, however, high intracellular Pten levels associated with insufficient activation of PI3K upon BCR engagement block the production of PIP3 and consequently inhibit the activation of downstream PIP3-dependent anti-apoptotic signaling components including AKT. Pten may also be directly involved in apoptosis activation via regulating intracellular ROS levels and release of cytochrome $c$.

Among the multiple signaling pathways activated downstream, the PI3K/Akt pathway appears to be a major determinant of immunogenic cell survival and proliferation. Through the generation of PIP3, many PH (pleckstrin homology) domain-containing proteins including Gab1/2, Akt, Btk, and PLC- $\gamma$ are recruited to the plasma membrane and become activated. Akt has been shown to regulate cell survival via inactivation of caspase, Bad and Bim, and to facilitate G1-S cell cycle progression by blocking p130 and p27-kip1 expression. PLC- $\gamma$-mediated PKC $\beta$ activation further recruits the CARMA1/Bcl10/ MALT1/IKK complexes, leading to activation of NF$\kappa \mathrm{B}$. Both Akt and Rel/NF- $\kappa \mathrm{B}$ synergistically regulate the expression and activation of cell survival and cell cycle proteins, such as BclX, Bfl-1, Mcl-1, Cyclin E, and E2F3 $[45,46]$, thus promoting immune response by mature B cells. Suppression of this positive signaling axis in B cells via PI3K (p85) or c-Rel deficiency renders mature $\mathrm{B}$ cells hypersensitive to apoptosis and growth arrest following BCR stimulation [23, 24, 47].
In essence, immature B cells with elevated Pten levels behave similarly to the response of the PI3K or c-Rel knockout mature B cells upon BCR ligation. In fact, the reported multiple positive signaling defects in immature B cells $[18,20,21,48]$, including impaired Gab1/2 activation, phosphatidylinositide-4,5-bisphosphate (PI4,5-P2) hydrolysis, PKC activation, Akt phosphorylation, Bcl-2 and Cyclin E expression, could be attributed to specific blockade of the PI3K/Akt pathway as a result of high Pten levels. Elevated Pten levels and impaired PI3K activation will hinder the production of PIP3 and the recruitment of $\mathrm{PH}$ domain-containing proteins including Gab1/2, Akt, Btk, and PLC- $\gamma$. Inadequate PLC- $\gamma$ activation leads to impaired (PI-4,5-P2) hydrolysis and impaired PKC activation, which explain the impaired IKK and Rel/NF- $\kappa \mathrm{B}$ activation [20]. Of note, poor Gab1/2 activation in immature $\mathrm{B}$ cells may result in decreased PI3K activity as observed in the present study (Figure 3C) since Gab1/2 is known to mediate a signal amplification process critical for PI3K activation [48, 49]. Taken 
together, our studies, including the data presented here, suggest a critical Pten-dependent PI3K/AKT/NF- $\kappa \mathrm{B}$ signaling deficit that controls BCR-mediated apoptosis and negative selection of immature or self-reactive B cells.

An issue raised by our present work is how Pten directly or indirectly links to the mitochondrial apoptotic pathway. We propose that Pten may transmit BCRinduced death signaling through several means. First, high Pten levels and impaired PI3K/NF- $\mathrm{KB}$ activity may obstruct the production of Bcl-2 family pro-survival proteins. As a result, the pro-apoptotic proteins Bim, Bax and Bak may assist in initiating mitochondrial death $[16,17]$. Second, Pten-dependent AKT inhibition may contribute to Bim expression as suggested by others [16]. In this model, Bim expression is induced by FOXO transcription factors, which are activated when AKT is inhibited [50]. Third, Pten may directly translocate into the mitochondria where it promotes production of reactive oxygen species (ROS). This possibility is supported by an observation that Pten is able to promote neural cell death by inducing ROS production within mitochondria [40].

Our work provides additional explanations for phenotypes observed in $b P T E N^{\text {Flox/Flox }}$ mice $[31,32]$. In such mice, a marked increase in autoreactive antibodies against self-antigens, splenomegaly, and substantial accumulation of $\mathrm{B} 1 \mathrm{a}$ and $\mathrm{MZ} \mathrm{B}$ cells are observed, while the total absolute number of peripheral immature $\mathrm{B}$ cells is increased by one- to three-folds [31, 32]. Concurrent with these observations, we notice a significant expansion of immature B cells in irradiated auto-reconstituted $C D 19^{\mathrm{Cre} / \mathrm{P}}$ PTEN ${ }^{\text {Flox/Flox }}$ mice. Recent reports indicate that a small fraction of transitional immature B cells are precursors of MZ B cells [51]. Hence, we hypothesize that the observed increase in autoantibodies may derive from self-reactive B1a and marginal zone B cells that originate from self-reactive immature B cells bypassing clonal deletion due to loss of Pten at the transitional stage.

In summary, the combined results of our biochemical and genetic studies lead us to conclude that Pten is an essential and selective death signal mediator for BCRinduced apoptosis, and that differential intracellular Pten levels are a fundamental determinant of whether BCR signaling leads to cell death or cell survival. Our findings describe a novel mechanism by which clonal deletion and negative selection of immature B cells may occur. Nonetheless, additional work is required to further decipher how higher Pten level is achieved in immature B cell, how Pten controls the initiation of mitochondrial death and survival pathways in immature B cells, and whether Pten is required for elimination of self-reactive $B$ cells.

\section{Materials and Methods}

\section{Generation of mouse strains}

To generate B cell-specific Pten-depleted mice, Pten ${ }^{\text {Flox/Flox }}$ mice from Dr Pandolfi's team [44] were crossed with $\mathrm{CD} 19^{\mathrm{Cre} /+}$ transgenic mice purchased from Jackson Laboratories. Mouse genotyping was performed by PCR using tail DNA as described previously [44] or following the protocols from Jackson Laboratories, and further verified at the protein expression level as shown in Figure 1. Mice that were 8-12 weeks old were used in all experiments. $J N 2^{-/}$mice and $\mathrm{E}_{2} \mathrm{Fl}^{-/}$mice were also purchased from Jackson Laboratories. The mice were maintained under specific pathogenfree conditions at Weill Medical College of Cornell University.

\section{Cell culture}

Mature and immature B cells were isolated from untreated mice and sublethally (500 rad) irradiated mice by complement-mediated lysis and Percoll gradient as described previously [20, 22, 52], and cultured in RPMI 1640 media containing 10\% fetal calf serum (Cellgro), 1\% penicillin, 1\% streptomycin (both Life Sciences $\mathrm{BRL}$ ), and $50 \mu \mathrm{M} \beta$-mercaptoethanol (Sigma). For survival and cell cycle experiments, $2 \times 10^{6} / \mathrm{ml} \mathrm{B}$ cells in the presence or absence of $10 \mu \mathrm{g} / \mathrm{ml}$ of goat anti-mouse IgM F(ab')2 (anti-IgM, Jackson ImmunoResearch Laboratories) were plated per well in 24-well polystyrene flat-bottom plates (Corning) in $1000 \mu \mathrm{l}$ of total culture volume. For caspase experiments, the following combinations of agents were added for 12 or $24 \mathrm{~h}$ at $37^{\circ} \mathrm{C}: 10 \mu \mathrm{g} / \mathrm{ml}$ of goat anti-mouse IgM F(ab')2, $50 \mu \mathrm{M}$ of z-VAD-fmk (Enzyme System Products), a pan-caspase inhibitor, or DSMO alone. For the PI3K assay, $2 \times 10^{6} \mathrm{~B}$ cells were plated per well in 24 -well polystyrene flat-bottom plates (Corning) in $2 \mathrm{ml}$ final culture volume, with 10 $\mu \mathrm{g} / \mathrm{ml}$ of goat anti-mouse IgM F(ab')2 added for the indicated time at $37^{\circ} \mathrm{C}$. Following culture, B cells were immediately put on ice, washed with $1 \times$ cold PBS, then lysed by an appropriate buffer (see below).

\section{Flow cytometry}

The following antibodies were used for FACS analysis: antiCD24 (HSA), anti-CD21, anti-B220 (RA3-6B2), AA4.1, labeled with different fluorescent probes including R-phycoerythrin (PE), FITC, and Allophyocyanin (APC), all purchased from Pharmigen or eBioscience. Anti-Pten (clone 6H2.1, ABM-2052) was purchased from Cascade, and its secondary antibody is FITC-antimouse IgG2a (Clone RMG2a-62, Biolegend, 407105). Isotypematched immunoglobulin was used as a non-specific staining control for all staining experiments. Cells were stained with surface markers for 30-60 min at $4{ }^{\circ} \mathrm{C}$, then washed in $1 \times$ PBS and resuspended in $0.5 \mathrm{ml} 1 \times \mathrm{PBS}$ with $0.5 \% \mathrm{BSA}$. For PIP3 assays, PIP3 levels were measured using a biotin-labeled antibody against anti-PI-3,4,5-P 3 (a gift from Dr Paul Neilsen, Echelon, Salt Lake City, UT) and FACS following a published protocol [32]. For intracellular Pten staining, total splenocytes freshly prepared from non-irradiated mice were fixed in $1.5 \%$ formaldehyde, permeabilized by $60 \%$ methanol, and then stained by PerCP-anti-B220, APC-AA4.1, anti-Pten. After washing, the cells were stained by the secondary antibody FITC-anti-mouse IgG2a. Based on B220/ AA4.1 expression profiles, mature $\left(\mathrm{B}_{22} 0^{+} \mathrm{AA} 4.1^{\circ}\right)$ and immature $\left(\mathrm{B} 220^{+} \mathrm{AA} 4.1^{+}\right) \mathrm{B}$ cells were gated and their intracellular Pten levels were quantified (median fluorescence intensity as shown in 
Figure 5) by flow cytometry.

\section{Apoptosis and cell cycle assays}

Mitochondrial membrane potential was assayed using the fluorescent potentiometric dye JC-1 (Molecular Probe). JC-1 accumulates in the mitochondrial space in a membrane potential-dependent manner. The dye exists as a monomer at low concentrations and yields green fluorescence, similar to fluorescein. At higher concentrations, the dye aggregates in a manner that yields red fluorescence, similar to PE. Briefly, cells were cultured at a density of $0.5-1.0 \times 10^{6}$ cells $/ \mathrm{ml}$. For each condition, $1 \mathrm{ml}$ of cells was treated for the indicated time. $0.3 \mathrm{ml}$ of the cells was mixed with $0.3 \mathrm{ml}$ of staining solution (complete medium containing $0.5 \mu \mathrm{g} / \mathrm{ml} \mathrm{JC}-1$ ). Cells were stained for $30 \mathrm{~min}$ in a $37{ }^{\circ} \mathrm{C}$ incubator $\left(5 \% \mathrm{CO}_{2}\right)$. After staining, cells were washed at room temperature with $1 \times \mathrm{PBS}$. The cell pellet was then resuspended in $0.5 \mathrm{ml} 1 \times \mathrm{PBS}$, and JC-1 fluorescence was analyzed by FACS. For PI staining assays, $2 \times 10^{6} / \mathrm{ml}$ of B cells were cultured in 24-well flat-bottom plates with $10 \mu \mathrm{g} /$ $\mathrm{ml}$ of goat anti-mouse IgM F(ab')2. At the indicated time points, cells were collected and stained with a solution containing $50 \mu \mathrm{g} /$ $\mathrm{ml} \mathrm{PI,} 20 \mathrm{ng} / \mathrm{ml}$ RNase A, 0.1\% Triton X-100, and 0.1\% sodium citrate. Duplicate samples were then analyzed by FACS (BectonDickinson) using CellQuest software, and the percentage of apoptotic cells $(<2 \mathrm{~N}$ DNA content) or $\mathrm{S}$ and $\mathrm{G} 2 / \mathrm{M}$ phase cells $(\geq 2 \mathrm{~N}$ DNA content) was quantified. For PI exclusion and B220/AA4.1 combined staining assays, $1 \mathrm{ml}\left(5 \times 10^{6}\right.$ cells $)$ of total splenocytes isolated from non-irradiated mice by a standard protocol was stimulated with $10 \mu \mathrm{g} / \mathrm{ml}$ anti-IgM for the indicated time periods, and then stained with $500 \mu \mathrm{l}$ of cold $1 \times$ PBS containing $0.5 \%$ BSA, $1 \mu \mathrm{g}$ PI /ml, PerCP-anti-B220, and APC-AA4.1. Using flow cytometry, the percentage of viable mature and immature $\mathrm{B}$ cells were determined by the B220/AA4.1 expression profile (mature B cells, B220 ${ }^{+}$AA4. $1^{-}$; immature B cells, B220 ${ }^{+} \mathrm{AA} 4.1^{+}$) after gating on propidium iodine negative cells. Viability results were calculated using the following formula: viability $(\%)=$ numbers of viable cells remaining after anti-IgM treatment for the specified time periods/numbers of viable cells at $0 \mathrm{~h} \times 100$.

\section{Immunoprecipitation and PI3K activity assays}

Protocol was modified from a previously published version [53]. Cells were lysed at $4{ }^{\circ} \mathrm{C}$ in $200 \mu \mathrm{l}$ ice-cold lysis buffer $(137 \mathrm{mM}$ $\mathrm{NaCl}, 2.7 \mathrm{mM} \mathrm{KCl}, 1 \mathrm{mM} \mathrm{MgCl} 2,1 \mathrm{mM} \mathrm{CaCl}_{2}, 1 \% \mathrm{NP} 40,10 \%$ glycerol, $1 \mathrm{mg} / \mathrm{ml} \mathrm{BSA,} 20 \mathrm{mM}$ Tris, $0.5 \mathrm{mM}$ sodium orthovanadate, $0.2 \mathrm{mM}$ PMSF, $10 \mu \mathrm{g} / \mathrm{ml}$ leupeptin, pepstatin A, and aprotinin). Agarose beads were prepared by adding $2 \mu \mathrm{l}$ of anti-phosphotyrosine $(1 \mu \mathrm{g} / \mu \mathrm{l}$ clone $4 \mathrm{G} 10$, Upstate Biotechnology, catalog\# 16-125) and $50 \mu \mathrm{l}$ (25 $\mu \mathrm{l}$ packed beads) of PBS-washed protein A agarose bead slurry to $500 \mu \mathrm{l}$ PBS in a microcentrifuge tube. The reaction mixture was gently rocked at $4{ }^{\circ} \mathrm{C}$ for $1 \mathrm{~h}$, centrifuged by gentle pulsing to precipitate beads, supernatant discarded, washed $2 \times$ times with cold PBS, and resuspended in an appropriate volume of PBS. Immunoprecipitation was carried out by incubating $50-80 \mu \mathrm{g}$ of cell lysate (diluted to $450 \mu \mathrm{l}$ with PBS) with $50 \mu \mathrm{l}$ of agarose beads for $1 \mathrm{~h}$ at $4{ }^{\circ} \mathrm{C}$ with gentle rocking. Beads were then washed $2 \times$ with cold PBS, $1 \times$ with kinase buffer $(10 \mathrm{mM}$ Tris, 10 $\mathrm{mM} \mathrm{MgCl}_{2}$ ). The kinase reaction was carried out by resuspending pelleted beads in $50 \mu \mathrm{l}$ of kinase buffer containing $10 \mu \mathrm{g}$ of phosphatidylinositol (PI), $10 \mu \mathrm{Ci} \gamma-{ }^{32} \mathrm{P}$-ATP per $50 \mu \mathrm{l}$ reaction, and incubated for $30 \mathrm{~min}$ at room temperature. Lipids, including PI3K- catalyzed synthesis product PIP, were then extracted from the reacting mixture with $150 \mu \mathrm{l}$ chloroform. The amount of PI phosphorylated by $\mathrm{PI} 3 \mathrm{~K}$ was analyzed by thin layer chromatography (TLC) using $\mathrm{CH}_{3} \mathrm{Cl}: \mathrm{CH}_{3} \mathrm{OH}: \mathrm{H}_{2} \mathrm{O}=90: 70: 14.6$ as a developing agent.

\section{Immunoblot assays}

Cells were lysed in $50 \mathrm{mM}$ HEPES (pH 7.5), $150 \mathrm{mM} \mathrm{NaCl}$, $1 \mathrm{mM}$ EDTA, $2.5 \mathrm{mM}$ EGTA, $1 \mathrm{mM}$ DTT, 0.1\% Tween-20, 10\% glycerol, $10 \mathrm{mM} \beta$-glycerophosphate, $1 \mathrm{mM}$ sodium fluoride, $0.1 \mathrm{mM} \mathrm{Na} \mathrm{VO}_{4}, 0.2 \mathrm{mM}$ PMSF, $5 \mu \mathrm{g} / \mathrm{ml}$ aprotinin, $5 \mu \mathrm{g} / \mathrm{ml}$ leupeptin, $2.5 \mathrm{mM}$ sodium pyrophosphate, and protein concentrations determined by Bradford assay (Bio-Rad). Around 30-40 $\mu \mathrm{g}$ of whole-cell lysate was loaded onto SDS-PAGE and transferred onto PVDF membrane (Millipore). Blots were probed with the following antibodies diluted into $1 \%$ non-fat milk in $10 \mathrm{mM}$ Tris saline ( $\mathrm{pH} 7.4$ ) containing $0.05 \%$ Tween-20 (TBS-T): anti-AKT, antiphospho-AKT (Thr 308), anti-phospho-AKT (Ser 473), all from Cell Signaling; anti-p85 and anti-p110 (Santa Cruz). Horseradish peroxidase-conjugated anti-rabbit secondary antibody (NA934) and anti-mouse secondary antibody (NA931) were purchased from Amersham. ECL plus chemiluminescence detection system was used to visualize Western blots (RPN 2132, Amersham). All Western blot experiments have been confirmed in multiple experiments using separate sets of cell lysates.

\section{Generation of immature $B$ cells infected by retrovirus}

Following the protocol published previously [20], retroviruses (pMIGR1 and pMyr-AKT-HA) were grown in 293T cells and assayed for viral titer by infecting NIH3T3 cells. Bone marrow extracts of female C57BL/6 mice were ablated with 5-fluorouracil (5-FU, $250 \mathrm{mg} / \mathrm{kg}$ weight) as previously described [41]. Bone marrow stem cells were cultured for one day in six-well plates with a cocktail of the following cytokines: IL-3 (6 ng/ml), IL-6 (10 ng/ $\mathrm{ml}$ ) and stem cell factor ( $\mathrm{SCF}, 100 \mathrm{ng} / \mathrm{ml})$. Retroviral supernatant was added to bone marrow stem cells, which were cultured for an additional 4-6 days. The cells were collected and injected into lethally irradiated mice $(850 \mathrm{rad})$. Immature B cells were harvested at 14 days post-transplant.

\section{Acknowledgments}

We thank Kendall Smith, Selina Chen-Kiang and Andrea Cerutti (Weill Medical College of Cornell University, USA) for discussion and scientific editing; John Monroe (University of Pennsylvania, USA) and Edward Clark (University of Washington) for critical review of the manuscript; Paul Neilsen, Glenn Prestwich (Echelon Biosciences, USA) for antibodies against PIP3 and PIP2; Thomas Franke (Columbia University, USA) for the myr-AKT-HA expression vector and thoughtful discussion. This work was supported by grants from the National Institutes of Health, USA.

\section{References}

1 Healy JI, Goodnow CC. Positive versus negative signaling by lymphocyte antigen receptors. Annu Rev Immunol 1998; 16:645-670.

2 Nemazee D. Receptor editing in lymphocyte development and 
central tolerance. Nat Rev Immunol 2006; 6:728-740.

3 Lawton AR, III, Cooper MD. Modification of B lymphocyte differentiation by anti-immunoglobulins. Contemp Top Immunobiol 1974; 3:193-225.

4 Nemazee DA, Burki K. Clonal deletion of B lymphocytes in a transgenic mouse bearing anti-MHC class I antibody genes. Nature 1989; 337:562-566.

5 Goodnow CC. Transgenic mice and analysis of B-cell tolerance. Annu Rev Immunol 1992; 10:489-518.

6 Murakami M, Tsubata T, Okamoto M, et al. Antigen-induced apoptotic death of Ly-1 B cells responsible for autoimmune disease in transgenic mice. Nature 1992; 357:77-80.

7 Strasser A. The role of BH3-only proteins in the immune system. Nat Rev Immunol 2005; 5:189-200.

8 Eeva J, Pelkonen J. Mechanisms of B cell receptor induced apoptosis. Apoptosis 2004; 9:525-531.

9 Gottlieb E, Armour SM, Harris MH, Thompson CB. Mitochondrial membrane potential regulates matrix configuration and cytochrome c release during apoptosis. Cell Death Differ 2003; 10:709-717.

10 Lakhani SA, Masud A, Kuida K, et al. Caspases 3 and 7: key mediators of mitochondrial events of apoptosis. Science 2006; 311:847-851.

11 Green DR, Kroemer G. The pathophysiology of mitochondrial cell death. Science 2004; 305:626-629.

12 Takada E, Hata K, Mizuguchi J. Requirement for JNK-dependent upregulation of BimL in anti-IgM-induced apoptosis in murine B lymphoma cell lines WEHI-231 and CH31. Exp Cell Res 2006; 312:3728-3738.

13 Shiokawa D, Shika Y, Araki S, et al. Stage-specific expression of DNasegamma during B-cell development and its role in B-cell receptor-mediated apoptosis in WEHI-231 cells. Cell Death Differ 2007; 14:992-1000.

14 Avramidou A, Kroczek C, Lang C, et al. The novel adaptor protein Swiprosin-1 enhances BCR signals and contributes BCR-induced apoptosis. Cell Death Differ 2007; 14:1-12.

15 Katz E, Deehan MR, Seatter S, et al. B cell receptor-stimulated mitochondrial phospholipase A2 activation and resultant disruption of mitochondrial membrane potential correlate with the induction of apoptosis in WEHI-231 B cells. J Immunol 2001; 166:137-147.

16 Enders A, Bouillet P, Puthalakath $\mathrm{H}$, et al. Loss of the proapoptotic BH3-only Bcl-2 family member Bim inhibits BCR stimulation-induced apoptosis and deletion of autoreactive B cells. J Exp Med 2003; 198:1119-1126.

17 Takeuchi O, Fisher J, Suh H, et al. Essential role of BAX,BAK in B cell homeostasis and prevention of autoimmune disease. Proc Natl Acad Sci USA 2005; 102:11272-11277.

18 Monroe JG. B-cell antigen receptor signaling in immaturestage B cells: integrating intrinsic and extrinsic signals. Curr Top Microbiol Immunol 2000; 245:1-29.

19 King LB, Norvell A, Monroe JG. Antigen receptor-induced signal transduction imbalances associated with the negative selection of immature B cells. J Immunol 1999; 162:2655-2662.

20 Feng B, Cheng S, Hsia CY, et al. NF-kappaB inducible genes $\mathrm{BCL}-\mathrm{X}$ and cyclin $\mathrm{E}$ promote immature B-cell proliferation and survival. Cell Immunol 2004; 232:9-20.

21 Kovesdi D, Paszty K, Enyedi A, et al. Antigen receptor-mediated signaling pathways in transitional immature B cells. Cell
Signal 2004; 16:881-889.

22 Cheng S, Hsia CY, Leone G, Liou HC. Cyclin E and Bcl-xL cooperatively induce cell cycle progression in c-Rel-/- B cells. Oncogene 2003; 22:8472-8486.

23 Owyang AM, Tumang JR, Schram BR, et al. c-Rel is required for the protection of $\mathrm{B}$ cells from antigen receptor-mediated, but not Fas-mediated, apoptosis. J Immunol 2001; 167:49484956.

24 Tumang JR, Owyang A, Andjelic S, et al. c-Rel is essential for B lymphocyte survival and cell cycle progression. Eur J Immunol 1998; 28:4299-4312.

25 Grumont RJ, Rourke IJ, O'Reilly LA, et al. B lymphocytes differentially use the Rel and nuclear factor kappaB1 (NFkappaB1) transcription factors to regulate cell cycle progression and apoptosis in quiescent and mitogen-activated cells. $J$ Exp Med 1998; 187:663-674.

26 Niiro H, Clark EA. Regulation of B-cell fate by antigen-receptor signals. Nat Rev Immunol 2002; 2:945-956.

27 Schulze-Luehrmann J, Ghosh S. Antigen-receptor signaling to nuclear factor kappa B. Immunity 2006; 25:701-715.

28 Andjelic S, Hsia C, Suzuki H, et al. Phosphatidylinositol 3-kinase and NF-kappa B/Rel are at the divergence of CD40-mediated proliferation and survival pathways. J Immunol 2000; 165:3860-3867.

29 Di Cristofano A, Kotsi P, Peng YF, et al. Impaired Fas response and autoimmunity in Pten+/- mice. Science 1999; 285:2122-2125.

30 Suzuki A, Yamaguchi MT, Ohteki T, et al. T cell-specific loss of Pten leads to defects in central and peripheral tolerance. Immunity 2001; 14:523-534.

31 Suzuki A, Kaisho T, Ohishi M, et al. Critical roles of Pten in B cell homeostasis and immunoglobulin class switch recombination. J Exp Med 2003; 197:657-667.

32 Anzelon AN, Wu H, Rickert RC. Pten inactivation alters peripheral B lymphocyte fate and reconstitutes CD19 function. Nat Immunol 2003; 4:287-294.

33 Fruman DA, Snapper SB, Yballe CM, et al. Impaired B cell development and proliferation in absence of phosphoinositide 3-kinase p85alpha. Science 1999; 283:393-397.

34 Suzuki H, Terauchi Y, Fujiwara M, et al. Xid-like immunodeficiency in mice with disruption of the p85alpha subunit of phosphoinositide 3-kinase. Science 1999; 283:390-392.

35 Rickert RC, Roes J, Rajewsky K. B lymphocyte-specific, Cremediated mutagenesis in mice. Nucleic Acids Res 1997; 25:2.

36 Norvell A, Monroe JG. Acquisition of surface IgD fails to protect from tolerance-induction. Both surface IgM- and surface IgD-mediated signals induce apoptosis of immature murine $\mathrm{B}$ lymphocytes. J Immunol 1996; 156:1328-1332.

37 Mihara M, Erster S, Zaika A, et al. p53 has a direct apoptogenic role at the mitochondria. Mol Cell 2003; 11:577-590.

38 Field SJ, Tsai FY, Kuo F, et al. E2F-1 functions in mice to promote apoptosis and suppress proliferation. Cell 1996; 85:549561.

39 Sabapathy K, Kallunki T, David JP, et al. c-Jun NH2-terminal kinase (JNK)1 and JNK2 have similar and stage-dependent roles in regulating $\mathrm{T}$ cell apoptosis and proliferation. $J$ Exp Med 2001; 193:317-328.

40 Zhu Y, Hoell P, Ahlemeyer B, Krieglstein J. PTEN: a crucial mediator of mitochondria-dependent apoptosis. Apoptosis 
2006; 11:197-207.

41 Feng B, Cheng S, Pear WS, Liou HC. NF- $\mathrm{KB}$ inhibitor blocks B cell development at two checkpoints. Med Immunol 2004; 3:1.

42 Stambolic V, MacPherson D, Sas D, et al. Regulation of PTEN transcription by p53. Mol Cell 2001; 8:317-325.

43 Allman D, Lindsley RC, DeMuth W, et al. Resolution of three nonproliferative immature splenic B cell subsets reveals multiple selection points during peripheral B cell maturation. $J$ Immunol 2001; 167:6834-6840.

44 Trotman LC, Niki M, Dotan ZA, et al. Pten dose dictates cancer progression in the prostate. PLoS Biol 2003; 1:E59.

45 Liou HC, Hsia CY. Distinctions between c-Rel and other NFkappaB proteins in immunity and disease. Bioessays 2003; 25:767-780.

46 Grossmann M, Nakamura Y, Grumont R, Gerondakis S. New insights into the roles of ReL/NF-kappa B transcription factors in immune function, hemopoiesis and human disease. Int $J$ Biochem Cell Biol 1999; 31:1209-1219.

47 Grumont RJ, Rourke IJ, Gerondakis S. Rel-dependent induc- tion of A1 transcription is required to protect B cells from antigen receptor ligation-induced apoptosis. Genes Dev 1999; 13:400-411.

48 Koncz G, Bodor C, Kovesdi D, Gati R, Sarmay G. BCR mediated signal transduction in immature and mature B cells. Immunol Lett 2002; 82:41-49.

49 Deane JA, Fruman DA. Phosphoinositide 3-kinase: diverse roles in immune cell activation. Annu Rev Immunol 2004; 22:563-598.

50 Greer E, Brunet A. FOXO transcription factors at the interface between longevity and tumor suppression. Oncogene 2005; 24:7410-7425.

51 Pillai S, Cariappa A, Moran ST. Marginal zone B cells. Annu Rev Immunol 2005; 23:161-196.

52 Hsia CY, Cheng S, Owyang AM, Dowdy SF, Liou HC. c-Rel regulation of the cell cycle in primary mouse B lymphocytes. Int Immunol 2002; 14:905-916.

53 Chen HC, Guan JL. Association of focal adhesion kinase with its potential substrate phosphatidylinositol 3-kinase. Proc Natl Acad Sci USA 1994; 91:10148-10152.

(Supplementary information is linked to the online version of the paper on the Cell Research website.) 